\title{
A Igreja do Mosteiro de Santa Maria das Júnias (Vila Real)
}

\section{Sofia Lovegrove}

\section{OpenEdition}

\section{Journals}

\section{Edição electrónica}

URL: http://journals.openedition.org/medievalista/373

DOI: 10.4000/medievalista.373

ISSN: 1646-740X

\section{Editora}

Instituto de Estudos Medievais - FCSH-UNL

\section{Refêrencia eletrónica}

Sofia Lovegrove, «A Igreja do Mosteiro de Santa Maria das Júnias (Vila Real) », Medievalista [Online], 14 | 2013, posto online no dia 01 julho 2013, consultado no dia 30 abril 2019. URL : http:// journals.openedition.org/medievalista/373 ; DOI : 10.4000/medievalista.373

(C) IEM 
Título: A Igreja do Mosteiro de Santa Maria das Júnias (Vila Real).

Um estudo histórico-arquitectónico

Autor(es): Sofia Lovegrove

Enquadramento Institucional: FCSH-UNL, Lisboa, Portugal

Contacto: lovegrove.sofia@gmail.com

Fonte: Medievalista [Em linha]. №14, (Julho - Dezembro 2013). Dir. José Mattoso.

Lisboa: IEM.

Disponível em: http://www2.fcsh.unl.pt/iem/medievalista/

ISSN: $1646-740 \mathrm{X}$

\section{Resumo}

A Igreja do Mosteiro de Santa Maria das Júnias localiza-se no actual distrito de Vila Real, concelho de Montalegre. A sua construção situar-se-á no século XII e enquadra-se no estilo românico. Considera-se a forte possibilidade da existência de uma estrutura religiosa de cronologia mais recuada, no mesmo espaço, embora desta não subsistam quaisquer vestígios, à excepção de algumas menções em documentos da época.

A sua história foi marcada por diversos momentos construtivos, directamente associados à conjuntura religiosa do reino de Portugal. Através da análise da sua estrutura arquitectónica, em paralelo com a história religiosa deste monumento, da região em que se insere e das ordens religiosas a que este esteve associado, procurou-se compreender a evolução histórica e arquitectónica do Mosteiro de Santa Maria das Júnias e, mais especificamente, da sua igreja.

Palavras-chave: Igreja românica, Santa Maria das Júnias, ordens religiosas, evolução histórico-arquitectónica. 


\section{Abstract}

The Church of the Monastery of Santa Maria das Júnias nowadays is located in the district of Vila Real, municipality of Montalegre. The construction of this building, in the romanesque style, must have taken place during the 12th century. There is a very strong possibility that there had been, in the same place, an older religious structures, although there is no evidence of such, except for references in some written documents of the time.

This church reveals several architectural alterations in different periods, directly related to the religious history of the Kingdom of Portugal. By analysing its arquitectural strutcture and considering the religious history and the religious orders related to this monument, an attempt has been made to understand the historical and architectural development of the Monastery of Santa Maria das Júnias and, more specifically, of its Church.

Keywords: Romanesque church, Santa Maria das Júnias, religious orders, historical and architectural evolution.

\section{A Igreja do Mosteiro de Santa Maria das Júnias (Vila Real). Um estudo histórico-arquitectónico}

Sofia Lovegrove

\section{Localização}

O mosteiro de Santa Maria das Júnias localiza-se na actual província de Trás-osMontes, distrito de Vila Real, concelho de Montalegre, a cerca de dois quilómetros a 
Sul da freguesia de Pitões das Júnias ${ }^{1}$. O mosteiro encontra-se implantado num vale na margem ocidental da Ribeira de Campesinho, em lugar ermo, de difícil visibilidade e acesso, actualmente integrado no Parque Nacional da Peneda-Gerês (fig. 1).

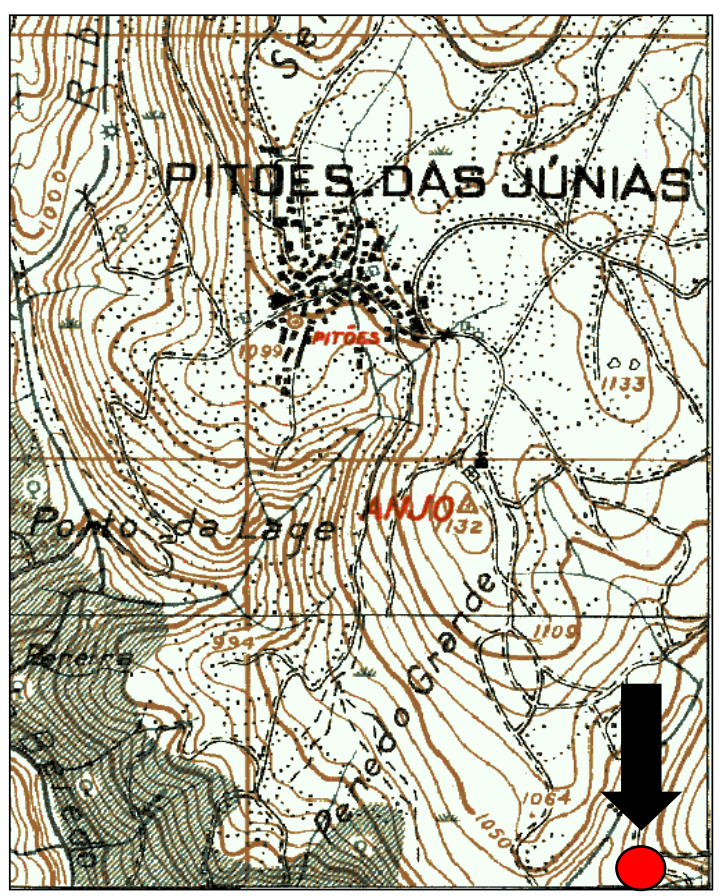

Fig. 1 - Localização do sítio em excerto da C.M.P.

«A busca inicial de lugares férteis e relativamente afastados correspondia às recomendações de São Bernardo, cuja regra proclamava o isolamento e a concentração espiritual, num regime de quase auto-subsistência, apenas com recurso ao trabalho de monges conversos» $»^{2}$. Através da proximidade a um curso de água e da prática da pastorícia, actividade económica que este lugar ainda hoje privilegia ${ }^{3}$, terão sido reunidas as condições necessárias e suficientes à sobrevivência do mosteiro e da sua comunidade monástica.

\footnotetext{
${ }^{1} \mathrm{O}$ mosteiro implanta-se num ponto com cerca de 1054 metros de altitude. Corresponde-lhe as seguintes coordenadas $-41^{\circ} 49^{\prime} 53^{\prime \prime} \mathrm{N}$ e $7^{\circ} 56^{\prime} 29^{\prime \prime} \mathrm{O}$.

2 REAL, Manuel Luís - "A construção cisterciense em Portugal durante a Idade Média". In RODRIGUES, Jorge (coord.) - Arte de Cister em Portugal e Galiza. Lisboa: Fundação Calouste Gulbenkian, 1998, pp. 48, 49.

${ }^{3}$ RODRIGUES, Jorge - "O mundo românico (sécs. XI-XIII)". In História da Arte Portuguesa. Vol. I. Lisboa: Círculo de Leitores, 1995, p. 236.
} 


\section{Evolução histórica e arquitectónica}

A opção de focar o presente estudo apenas na igreja deve-se ao facto de as dependências monásticas, excluindo o claustro, serem já posteriores ao período medieval ${ }^{4}$, e ao facto de esta ser, de todo o conjunto arquitectónico, o único elemento totalmente conservado. Será abordada a sua evolução arquitectónica, marcada por um número considerável de alterações, bem como a sua evolução histórica, às quais os diversos momentos construtivos se associam. Considera-se que ambas as vertentes de análise, tanto o ponto de vista material como histórico, se complementam e contribuem para a compreensão desta igreja no quadro mais abrangente da história religiosa de Portugal.

Segundo uma lenda local, dois cavaleiros, durante uma caçada, terão encontrado junto a um carvalho uma imagem de Nossa Senhora com o Menino e, mostrando a sua devoção, aí terão construído um pequeno local de culto. Por ter sido conservada pela tradição oral, a lenda apresenta ligeiras variações entre as versões existentes ${ }^{5}$. Poder-seia admitir que este primitivo lugar de culto, associado a esta história, «possa ter estado na origem de uma forma de vida eremítica, prelúdio da formação do subsequente mosteiro beneditino» ${ }^{6}$.

Em relação à origem histórica do mosteiro, verifica-se alguma divergência entre os autores. Alguns apoiam a hipótese de se tratar de uma fundação do século IX, primeiro ocupada por uma comunidade religiosa eremítica de Regra hispânica e só posteriormente «normalizada» pelos Beneditinos cluniacenses ${ }^{7}$. Gerhard N. Graf chega a propor a hipótese de que este possível eremitério tivesse sido destruído no contexto da

\footnotetext{
${ }^{4}$ BARROCA, Mário Jorge - "Mosteiro de Santa Maria das Júnias. Notas para o estudo da sua evolução arquitectónica". Revista da Faculdade de Letras da Universidade do Porto. $2^{\text {a }}$ Série, vol. XI, Porto: Faculdade de Letras da Universidade do Porto, 1994, p. 428.

${ }^{5}$ Veja-se, a título de exemplo, COSTA, João Alves da - Montalegre e terras de Barroso. Notas históricas sobre Montalegre, freguesias do concelho e região do Barroso. [s.l.]: Câmara Municipal de Montalegre, 1987, pp. 121-122; GUERREIRO, Manuel Viegas - Pitões das Júnias. Esboço de monografia etnográfica. Lisboa: Serviço Nacional de Parques, Reservas e Património Paisagístico, 1982, pp. 242244; FONTES, Lourenço - "Pitões das Júnias". In Actas do II Encontro Nacional das Associações de Defesa do Património Cultural e Natural. Braga: Associação para a Defesa, Estudo e Divulgação do Património Cultural; Associação Cultural os Amigos do Parque Nacional da Peneda-Gerês, 1981, p. 322.

${ }^{6}$ MAURÍCIO, Rui Paulo Duque - “O Mosteiro de Santa Maria das Júnias: a construção e a paisagem”. In Actas do II Colóquio Internacional - Cister. Espaços, Territórios, Paisagens. Vol. II. Lisboa: Ministério da Cultura/Instituto Português do Património Arquitectónico, 2000, p. 608.

${ }^{7}$ RODRIGUES, op. cit., p. 236; GRAF, Gerhard N. - Portugal Roman. Vol. 2. Paris: Zodiaque, 1987, p. 266.
} 
presença muçulmana na Península Ibérica, sendo depois reconstruído no século XII. Salienta-se, no contexto desta tese, a existência de dois documentos no Tombo do Mosteiro de Celanova referentes a Santa Maria das Júnias e datados de 953 e $1100^{8}$. É de referir ainda uma proposta interpretativa apresentada por Delmira Espada que, através da análise da métrica da igreja, sugere a existência de um local de culto que remontará ao período romano, nas fundações do qual se terá erigido o edifício românico ${ }^{9}$. No entanto, penso que esta hipótese teria de ser melhor fundamentada, antes de ser considerada como uma possibilidade.

Outros autores consideram que este mosteiro constitui uma fundação beneditina de raiz, já do século XII ${ }^{10}$. Os investigadores que defendem esta segunda hipótese apoiam-se sobretudo no facto de Frei Leão de S. Tomás referir, na Beneditina Lusitana, a existência do mosteiro de Santa Maria das Júnias filiado na Regra de S. Bento já no ano de $889^{11}$. No entanto, a referência a esta regra monástica reveste-se de anacronismo, dado que ela é introduzida em território português na segunda metade do século $\mathrm{XI}^{12} \mathrm{e}$, no caso do mosteiro de Santa Maria das Júnias, provavelmente só nos finais da primeira metade do século XII ${ }^{13}$.

A primeira referência segura de que se dispõe corresponde a uma inscrição gravada em dois silhares na fachada lateral Norte da igreja (fig. 2). De acordo com a transcrição de

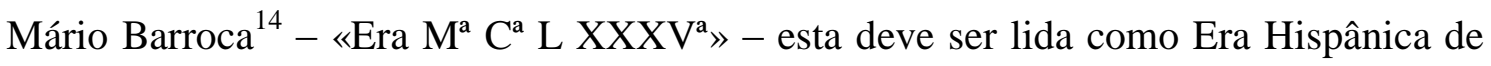
1185, Anno Domini de $1147^{15}$. Esta poderá constituir a inscrição comemorativa da

\footnotetext{
${ }^{8}$ ESPADA, Delmira - ““”Mosteiro de Santa Maria das Júnias”. Medievalista [Em linha]. No 4, (2008), pp. 624, 625. Disponível em http://www2.fcsh.unl.pt/iem/medievalista/MEDIEVALISTA4/medievalistaespada.htm; LIMA, Alexandra Cerveira Pinto Sousa - "O Mosteiro de Santa Maria das Júnias. Povoar e organizar um território de montanha". In Actas do II Colóquio Internacional - Cister. Espaços, Territórios, Paisagens. Vol. II. Lisboa: Ministério da Cultura/Instituto Português do Património Arquitectónico, 2000, pp. 6, 7.

${ }^{9}$ ESPADA, op. cit., pp. 22-24.

${ }^{10}$ BARROCA, op. cit.

${ }^{11}$ S. TOMÁS, Frei Leão de - Beneditina Lusitana. Tomo II. Ed. Crítica de José Mattoso. Lisboa: Imprensa Nacional-Casa da Moeda, 1974, p. 92.

${ }^{12}$ MATTOSO, José - Religião e Cultura na Idade Média Portuguesa. Lisboa: Círculo de Leitores, 2002, pp. 45-55.

${ }^{13}$ BARROCA, Mário Jorge - Epigrafia Medieval Portuguesa (862-1422). Vol. II, tomo I. Lisboa: Fundação Calouste Gulbenkian/Fundação para a Ciência e Tecnologia, 2000, p. 220.

${ }^{14}$ Idem, p. 219.

${ }^{15}$ Mário Barroca cita correcta, em nota de rodapé, a leitura feita por Maur Cocheril no Routier dês Abbayes Cisterciennes du Portugal, onde a data surge transcrita como ERA : M.CLXXX [ère chrétienne 1147] (ESPADA, op. cit., p. 10). Conferir, ainda, BARROCA, op. cit., p. 231.
} 
fundação do mosteiro, do início das obras, da sua conclusão ou da sagração da igreja. Acrescente-se que um documento conservado nos Arquivos da província de Orense indica que a sua data da fundação terá sido, aproximadamente, no ano de $1147^{16}$.

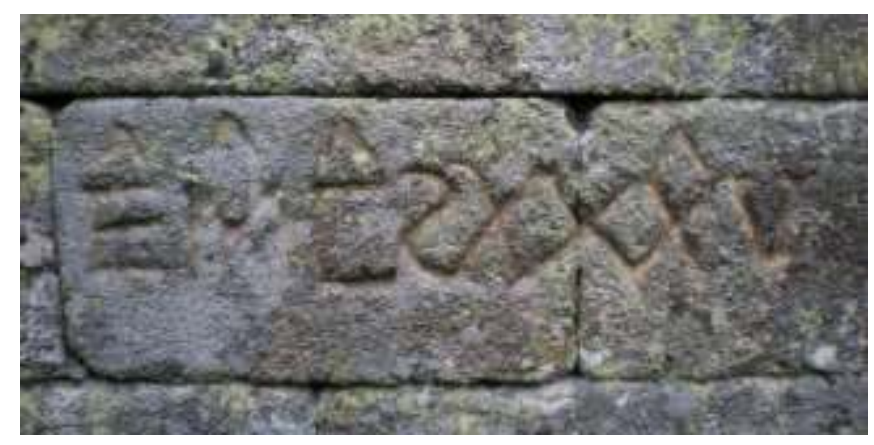

Fig. 2 - Inscrição da fachada lateral Norte da igreja ${ }^{17}$.

Mais tarde, dois diplomas de 21 de Novembro de 1248, ambos exarados no Liber Fidei, registam o processo de transferência do mosteiro de Santa Maria das Júnias da Ordem de S. Bento para a Ordem de Cister, altura em que passa a estar filiado, em períodos alternados, ao mosteiro de Oseira (Galiza) e ao mosteiro de Santa Maria de Bouro ${ }^{18}$. No primeiro diploma, o Arcebispo de Braga, D. João Egas (1245-1255), autoriza a mudança de Ordem depois de um apelo feito pelo Papa Inocêncio IV (1243-1254) através da bula Benigvolum et Benignum (23 de Junho de 1247). Nesta bula, refere-se explicitamente que Santa Maria das Júnias pertencia à Ordem de S. Bento e que pretendia abraçar a Ordem de Cister, o que está de acordo com o estilo românico que caracteriza a igreja. Assim, os autores mencionados consideram que a fundação do mosteiro, originalmente beneditina, tenha ocorrido nos finais da primeira metade do século XII, cerca de 1147, e que só em meados do século XIII, o mosteiro tenha adoptado a Ordem de Cister $^{19}$.

Desta forma, concluo que apesar de não possuirmos documentação explícita nem vestígios materiais, poder-se-á admitir a existência de um primitivo local de culto, mais

\footnotetext{
${ }^{16}$ GRAF, op. cit., p. 265.

${ }^{17}$ Todas as fotografias e desenhos não referenciados são da autoria da signatária.

${ }^{18}$ ESPADA, op. cit., p. 3.

${ }^{19}$ BARROCA, Mário Jorge - "Mosteiro de Santa Maria das Júnias. Notas para o estudo da sua evolução arquitectónica". Revista da Faculdade de Letras da Universidade do Porto. Porto: Faculdade de Letras da Universidade do Porto. $2^{\text {a }}$ Série, vol. XI (1994), pp. 420-423.
} 
tarde absorvido pelo movimento de renovação monástica e refundado segundo a Regra Beneditina, no século XII. De facto, não só era frequente a construção sobre locais onde haviam já existido templos primitivos - ou de que subsistia a tradição da sua existência -, como a generalidade das fundações estaria ligada a uma lenda miraculosa, sendo a maioria das fundações românicas assumida como uma refundação, invocando quase sempre uma tradição de sacralidade do local $^{20}$. Esta continuidade fazia-se por motivos de ordem simbólica e estratégica, pois um lugar santificado, geralmente associado a práticas cemiteriais (locais associados ao martírio de santos) ou a lendas e tradições fortemente enraizadas no imaginário local, dificilmente era abandonado ${ }^{21}$. Por este motivo, torna-se difícil, na maioria dos casos, determinar a primitiva fundação de mosteiros.

O movimento de renovação monástica acima referido deverá ser entendido no contexto do século XII. Este século foi caracterizado sobretudo pela afirmação e reconhecimento de Afonso Henriques como rei e Portugal como reino pelo papa Alexandre III (1179), bem como pelos conflitos com os reinos cristãos vizinhos e com os muçulmanos a Sul (contexto do movimento designado de «Reconquista Cristã»). Neste reino essencialmente rural, foi de grande importância a fixação dos mosteiros, que constituíam verdadeiros pólos de dinamização, protecção e organização do território. No caso específico do mosteiro de Santa Maria das Júnias, é possível que este tenha detido um importante papel enquanto local de passagem e apoio aos peregrinos. Tenha-se em conta a sua relativa proximidade a Santiago de Compostela, um dos mais importantes centros de peregrinação da Idade Média (fig. 3).

${ }^{20}$ RODRIGUES, op. cit., p. 204.

${ }^{21}$ Idem, p. 199. 


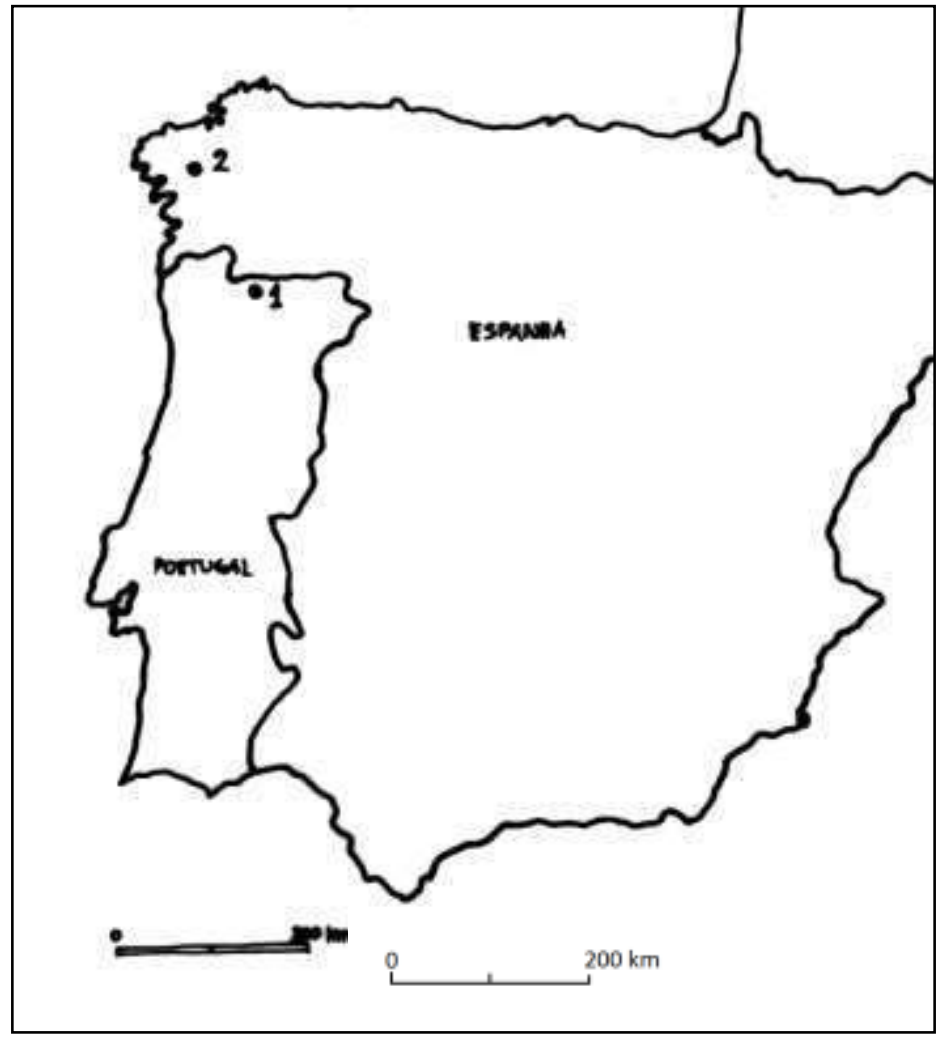

Fig. 3 - O mosteiro de Santa Maria das Júnias (1) e Santiago de Compostela (2) na Península Ibérica.

Mesmo considerando a tese que defende a sua fundação anterior ao século XII, a igreja e o mosteiro não apresentam vestígios evidentes desta primeira fase de construção. Por esse motivo, inicio a análise da evolução arquitectónica pela fase que corresponde à construção beneditina, a que geralmente se associa a epígrafe já referida. A este momento, iniciado no século XII, correspondem a igreja, composta por dois corpos de planta rectangular - a nave única e a cabeceira de uma só capela, bem como grande parte dos motivos decorativos que podem ser encontrados no interior e exterior do respectivo corpo ${ }^{22}$.

De uma segunda fase, correspondente à adopção dos costumes cistercienses (meados do século XIII), não há testemunhos evidentes de grandes mudanças arquitectónicas, mas

\footnotetext{
${ }^{22}$ MAURÍCIO, op. cit., p. 605.
} 
esta passagem terá trazido alguns benefícios económicos. A título de exemplo, no testamento de D. Afonso III, o mosteiro é contemplado com doação régia. O claustro terá sido construído anteriormente ${ }^{23}$ ou pouco depois da adesão a Cister. Dele resta o ângulo Nordeste, com um módulo de três arcos de volta perfeita, compreendido entre dois pilares rectangulares (fig. 11). Importa aqui referir que estes arcos constituem um raríssimo testemunho ao nível da arquitectura românica portuguesa, no actual território português.

O claustro, desde que foi construído, passou a desempenhar um papel fundamental na arquitectura do mosteiro, funcionando como elemento modelador dos restantes espaços construídos $^{24}$. No século XIV ou, possivelmente, ainda nos finais do século XIII ${ }^{25}$, devido ao assoreamento progressivo da plataforma onde se instalou o mosteiro, ter-se-á verificado a reconstrução e o alteamento da cabeceira da igreja, agora com uma construção plenamente gótica (embora mantendo o princípio original da planta), que se reflecte sobretudo ao nível do abobodamento em cruzaria de ogivas. Verificou-se também a abertura de duas janelas de arco quebrado, uma na fachada oriental e outra na fachada Norte, esta integrando também a representação escultórica de um monge, em posição horizontal, sob a janela (fig. 4).

23 ALMEIDA, Carlos Alberto Ferreira de - "Primeiras impressões sobre a arquitectura românica portuguesa". Revista da Faculdade de Letras do Porto. Porto: Faculdade de Letras. No 1, (1972), pp. 65 116; GRAF, op. cit.

${ }^{24}$ BARROCA, op. cit., pp. 426-428.

${ }^{25}$ MAURÍCIO, op. cit., p. 606. 


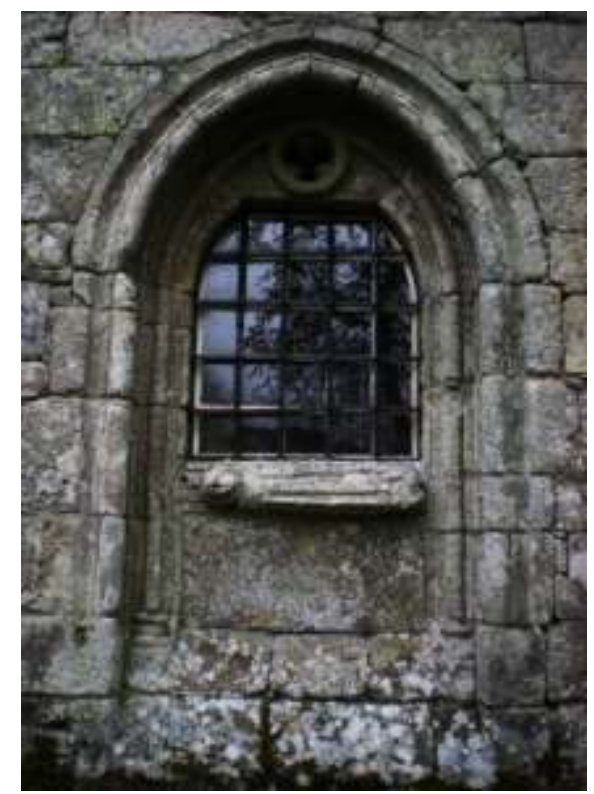

Fig. 4 - Janela setentrional da cabeceira, com escultura de monge jacente.

A mutilação dos lintéis originais dos portais laterais Norte e Sul, possivelmente mais tardiamente, estará também associada a este problema com que se debateu a comunidade monástica ${ }^{26}$.

No início do século XVI verificou-se o abandono do mosteiro, levando à rápida e profunda ruína das instalações monásticas ${ }^{27}$. A igreja terá sido poupada a estas alterações pois terá continuado a ser utilizada pela paróquia. Na segunda metade do século XVI, a vida monástica foi retomada. Neste século terá sido erguido o campanário e aberta a fresta na fachada ocidental. É provável que aquando da introdução destas alterações tenha deixado de funcionar o nártex ou alpendre de madeira que outrora aí se terá erguido, conforme testemunham os orifícios ainda visíveis na fachada, que indiciam encaixes de estruturas de madeira (fig. 5).

\footnotetext{
${ }^{26}$ BARROCA, op. cit., pp. 424, 425 .

${ }^{27}$ «Conhecemos algo acerca do estado de efectiva ruína das principais dependências monásticas no século XVI através do testemunho de Frère Claude de Bronseval que acompanhou a visitação do abade de Claraval aos mosteiros cistercienses da Península Ibérica: "sacristia, claustrum, calefactorium, infirmitorium, domus abbatialis et cetera local regularia sunt in ruina". Deduzimos ainda, a partir desta passagem, que as instalações seguiram no essencial a disposição da planta cisterciense embora com um programa limitado às necessidades de uma pequena comunidade como era a de Santa Maria das Júnias» (MAURÍCIO, op. cit., p. 610).
} 


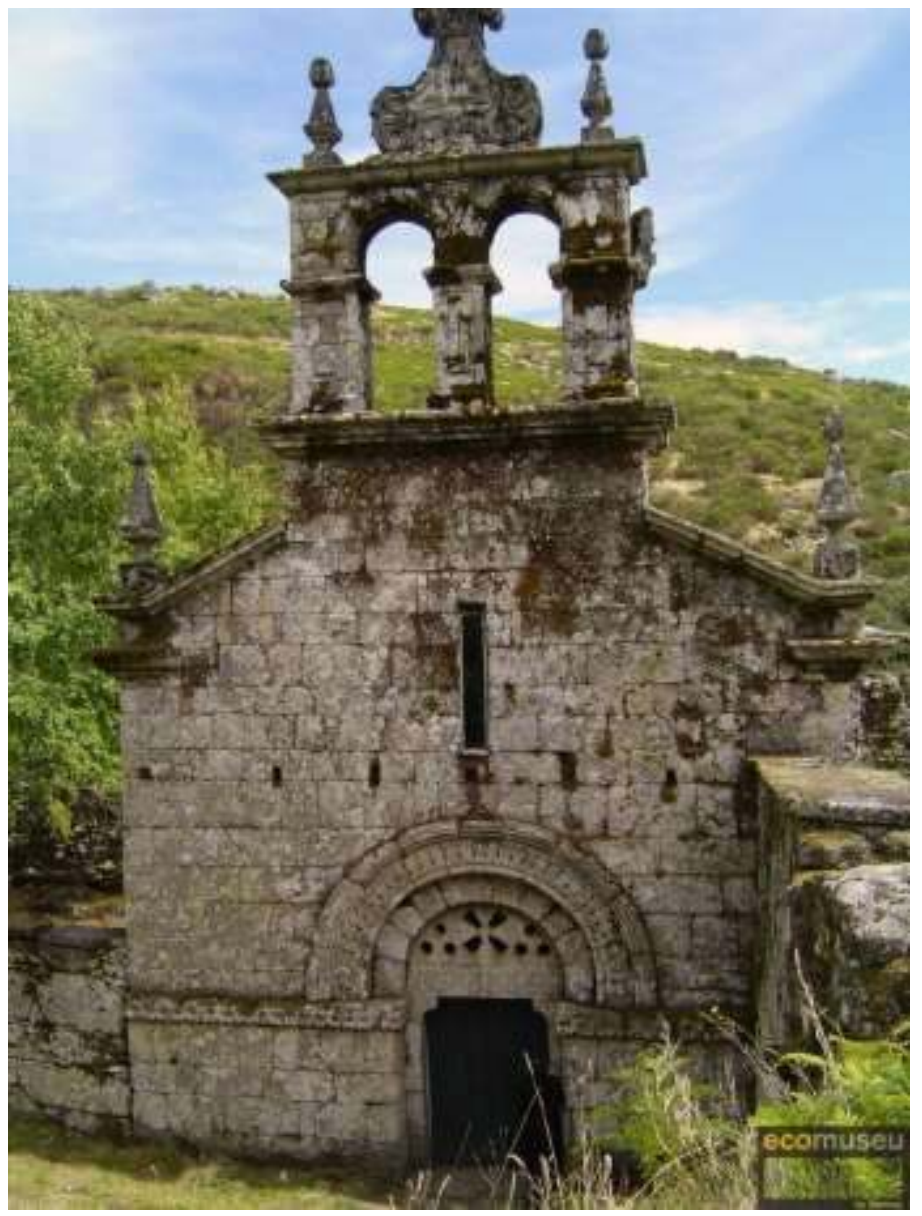

Fig. 5 - Fachada ocidental da igreja (fotografia gentilmente cedida pelo Ecomuseu do Barroso).

Os documentos parecem indicar que os séculos XVII e XVIII corresponderam a um período de posteridade da estrutura monástica, com a realização de diversas obras, nomeadamente, de alteamento do alçado $^{28}$. Talvez seja desta altura a mutilação dos lintéis dos portais laterais, de modo a altear o pé-direito das entradas (fig. 6), bem como a cornija das paredes laterais da nave (de recorte classista). É também intervencionado o telhado da capela-mor, actualmente de pendor único. As instalações monásticas de que

${ }^{28}$ Pelo ano de 1726 ter-se-ão despendido quantias significativas na reparação do madeiramento e para lajear a igreja. Verificam-se mais obras em 1728 quando Simon Duran, mestre canteiro recebe o pagamento a que tinha direito pelas obras que realizara no mosteiro. No mesmo ano, António da Casa, mestre carpinteiro, passa um recibo sobre certo trabalho que efectuara aqui (MAURÍCIO, op. cit., pp. 612-613). 
hoje subsistem apenas ruínas terão sido construídas neste período pós-medieval, entre os séculos XVI e XVIII' ${ }^{29}$.

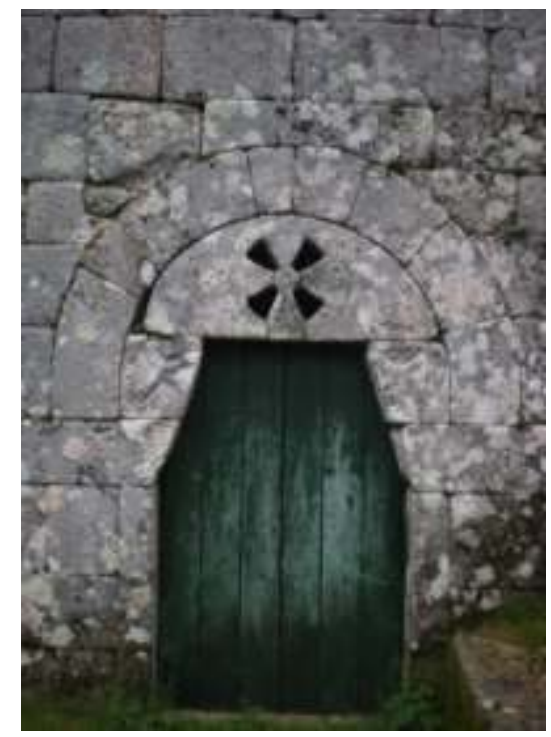

Fig. 6 - Portal lateral Sul.

Em 1834/35 é extinta a casa monástica. Segue-se um novo período de ruína que terá levado ao seu actual estado de conservação. Depois de definitivamente abandonado, o mosteiro sofreu duas intervenções a cargo da Direcção Geral dos Edifícios e Monumentos Nacionais (D.G.E.M.N.), primeiro em 1961, com acções de restauro, conservação e limpeza; depois em 1986, com obras de recuperação e beneficiação. Entre 1994 e 1995 decorreram intervenções arqueológicas no claustro e na cozinha, financiadas pelo Parque Nacional da Peneda-Gerês.

\section{Análise e descrição arquitectónica}

Começa-se por descrever a planta da igreja e, de seguida, apresenta-se a análise do exterior do edifício, focando-se primeiro na fachada principal e respectivo portal, nas fachadas laterais e seus portais e, por fim, na cabeceira. Segue-se a descrição do interior, primeiro da nave e, só depois, da cabeceira.

\footnotetext{
${ }^{29}$ BARROCA, op. cit., pp. 433-435.
} 
A igreja apresenta a orientação canónica (Oeste - Este), embora um pouco virada a Norte, possivelmente devido aos condicionantes do terreno. A sua planta é caracterizada por uma grande simplicidade, com corpo rectangular de uma só nave (sem transepto) e cabeceira constituída por uma única capela de terminação recta (fig. 7). Este constitui o modelo dominante do românico português. A igreja integra três portais - o da fachada ocidental e um em cada fachada lateral, perto da cabeceira. Terá tido também uma porta de acesso à sacristia na parede Sul da cabeceira, embora se encontre actualmente obstruída por silhares.

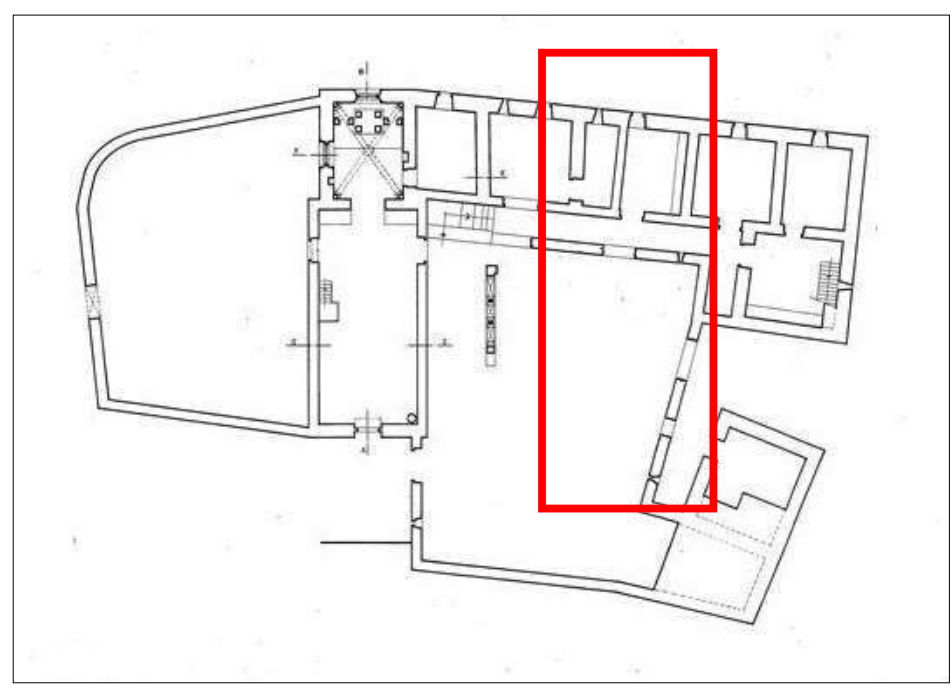

Fig. 7 - Planta da igreja e do mosteiro [www.monumentos.pt, adaptado].

Pelo exterior (figs. 8 e 9), a igreja apresenta uma grande simplicidade volumétrica, sendo composta pela junção de duas estruturas poliédricas, ambas de base rectangular, correspondentes ao corpo e à cabeceira. O seu corpo é em telhado de duas águas, enquanto a cabeceira é de pendor único (Sul - Norte). 


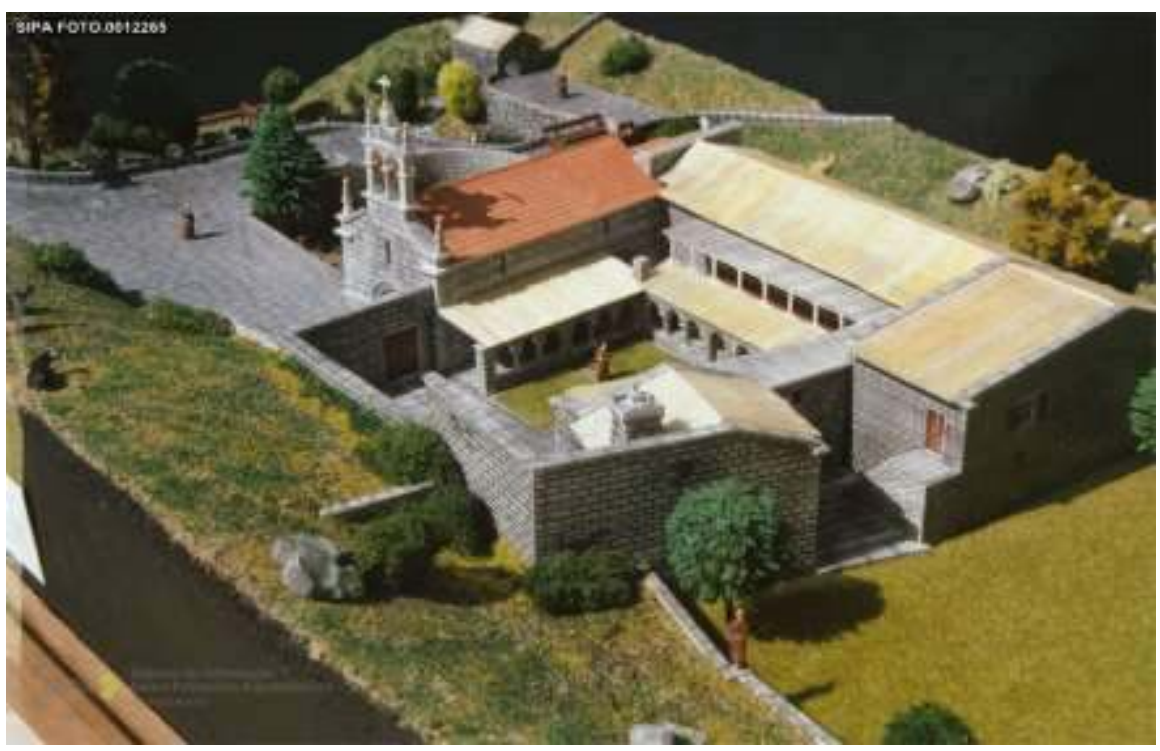

Fig. 8 - Reconstituição da igreja e do mosteiro, vista Sul [www.monumentos.pt].

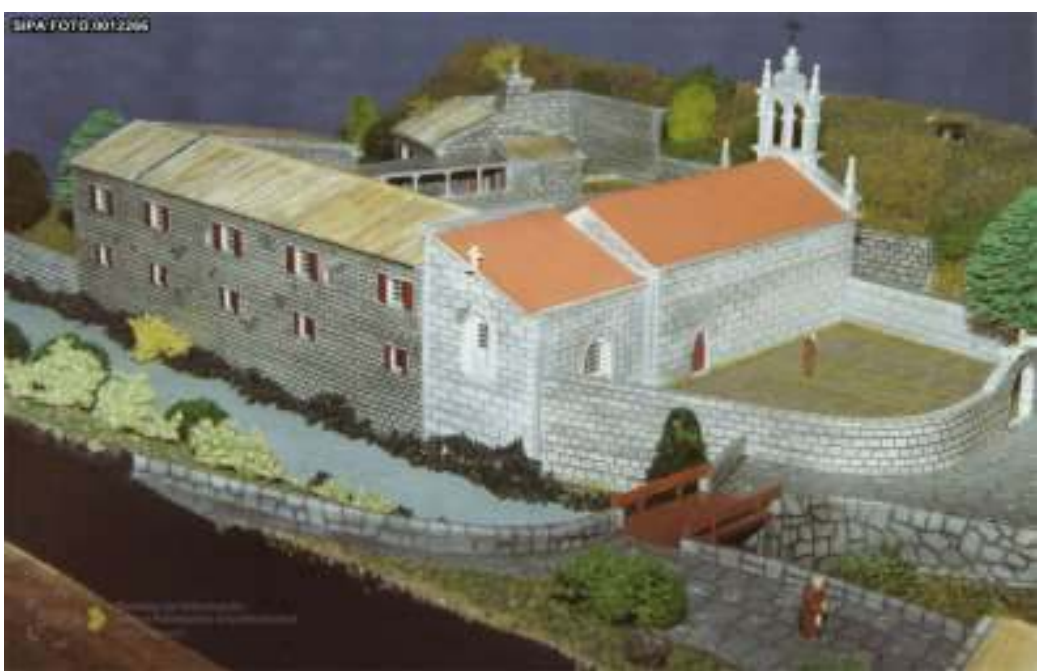

Fig. 9 - Reconstituição da igreja e do mosteiro, vista da margem esquerda da Ribeira de Campesinho [www.monumentos.pt].

No ponto de inflexão das duas águas da cobertura da nave, junto à cabeceira, encontrase uma cruz ornamentada com quatro folhas que irradiam do centro de uma circunferência, ultrapassando-a. Esta cruz é identificada como sendo românica ${ }^{30}$.

${ }^{30}$ FONTES, Lourenço - "Pitões das Júnias". In Actas do II Encontro Nacional das Associações de Defesa do Património Cultural e Natural. Braga: Associação para a Defesa, Estudo e Divulgação do Património Cultural; Associação Cultural os Amigos do Parque Nacional da Peneda-Gerês, 1981, p. 331. 
A fachada ocidental (fig. 5) é simétrica, de grande simplicidade e densidade mural, devido à reduzida fenestração (apenas um vão muito estreito), bem como à pedra utilizada (granito). Esta reflecte pelo exterior a composição interna da igreja - uma só nave. $\mathrm{O}$ friso que a percorre ao nível das impostas confere-lhe algum sentido de horizontalidade. A fachada é rematada por empena de cornija moldurada, truncada por um campanário mais tardio ${ }^{31}$, de dupla ventana (já sem sinos), encimado por uma cruz metálica com cata-vento, ladeada por dois pináculos com remate boleado, idênticos aos que se encontram nas extremidades da empena. Ao longo de toda a fachada, entre o portal e a fresta, encontram-se seis reentrâncias, possivelmente evidências de um antigo nártex.

A decoração da fachada ocidental concentra-se, sobretudo, no portal e no friso. O portal (fig. 10) é definido pelo uso do arco de volta perfeita, estruturado por duas arquivoltas a interna lisa e de arestas vivas e a exterior, de esquina boleada, decorada com o motivo de pontas de lança - e um friso que as envolve, apresentado três estreitos bocéis e um duplo ziguezague. O portal ocidental, tal como os restantes portais desta igreja, não possui colunas nem capitéis, encontrando-se as arquivoltas apoiadas directamente nas impostas, como é frequente se verificar na província de Trás-os-Montes. As impostas apresentam o motivo da palmeta bracarense. O tímpano apresenta no centro uma cruz vazada, circunscrita por duas circunferências concêntricas gravadas na pedra, e três orifícios circulares em ambos os lados da cruz, dispostos de maneira a formar um triângulo. O elemento sobre o qual se apoia o tímpano - o lintel - é ornado com bandas de quadrifólios quase incisos, i.e., motivos geométricos resultantes da intersecção de circunferências (a mesma construção geométrica que serve de base à construção da cruz vazada no tímpano). As consolas apresentam motivos decorativos geométricos, nomeadamente, círculos e alguns registos semelhantes aos do lintel, numa composição sem organização aparente.

\footnotetext{
${ }^{31}$ BARROCA, op. cit., pp. 433, 434; GRAF, op. cit., p. 267.
} 


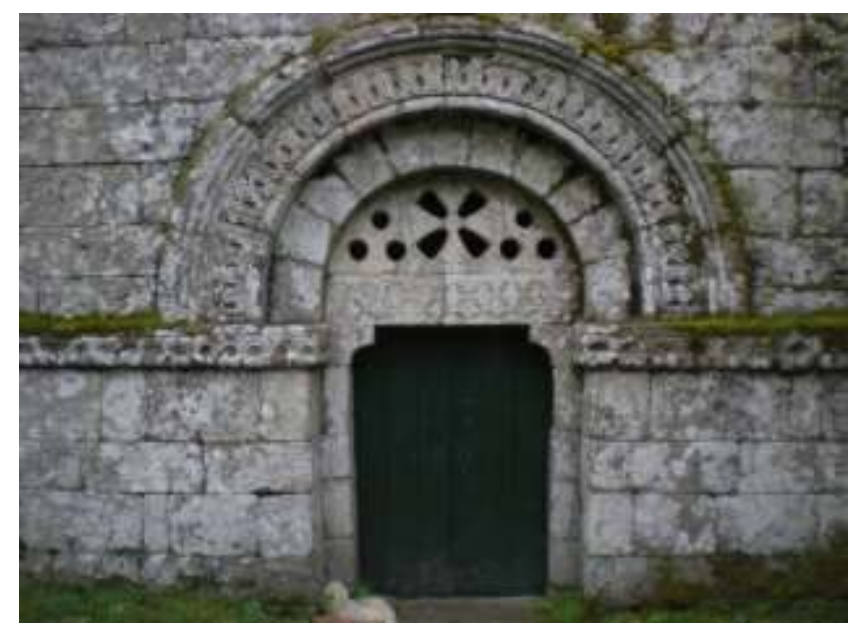

Fig. 10 - Portal ocidental.

Passando às fachadas laterais, estas apresentam, em termos gerais, características semelhantes. Enquanto a fachada lateral Norte está voltada para o cemitério, a fachada Sul encontra-se orientada para o claustro e restantes dependências monásticas. São fachadas simples e despojadas (fig. 11), com um portal junto à cabeceira e duas frestas estreitas, abertas sobre o friso e semelhantes à da fachada principal. Esta simplicidade e densidade mural é contrabalançada pela presença de cinco cachorros, um friso que corre sob as duas frestas e uma cornija moldurada, possivelmente já renascentista ${ }^{32}$, elementos que conferem à fachada um certo sentido de horizontalidade. A posição dos cachorros, a meio dos alçados, poderá ser interpretada como tendo servido de suporte a uma estrutura de madeira.

\footnotetext{
${ }^{32}$ ESPADA, op. cit., p. 9.
} 


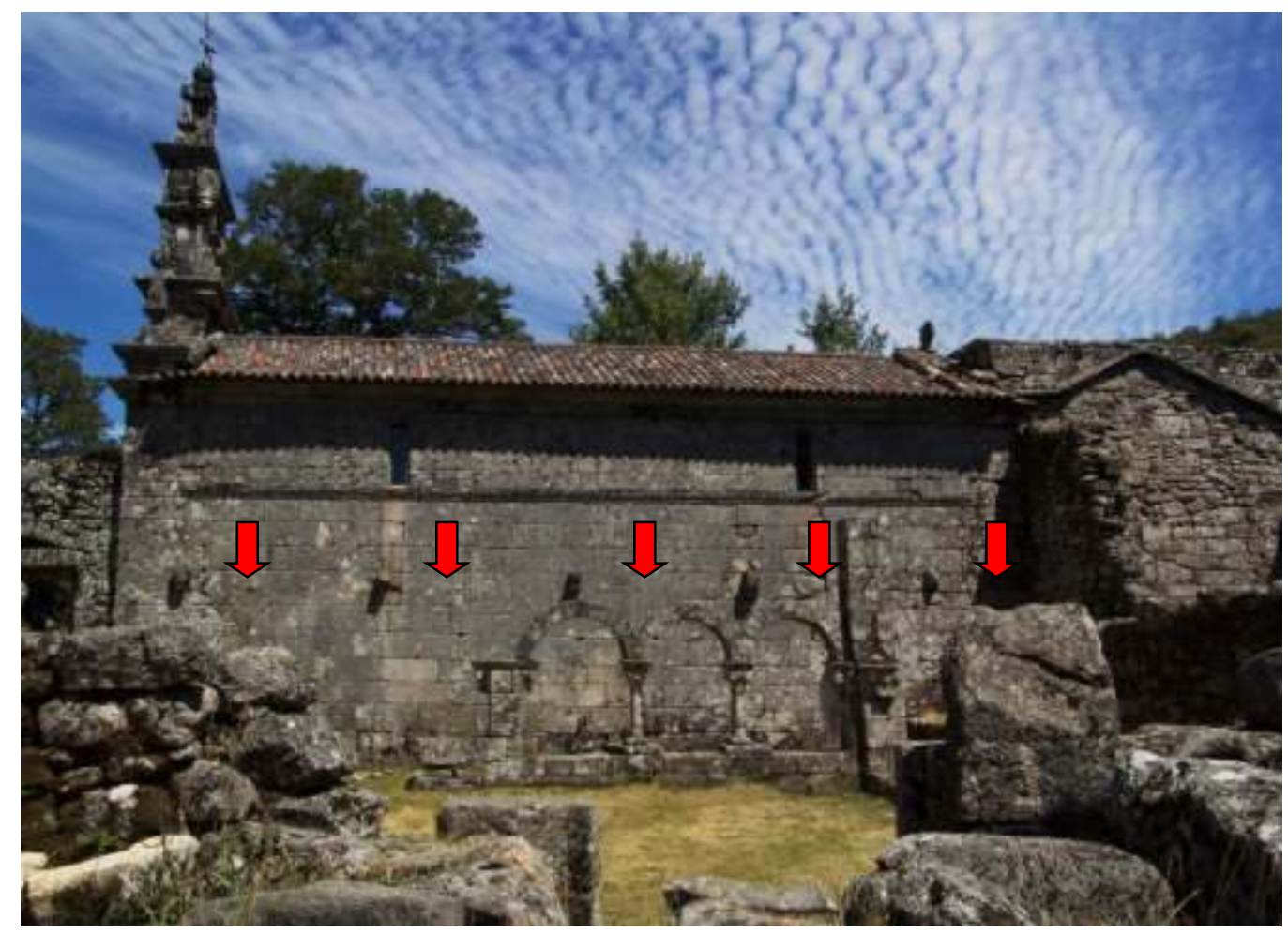

Fig. 11 - Fachada lateral Sul com indicação dos cachorros (fotografia gentilmente cedida pelo Ecomuseu do Barroso) [adaptado].

A decoração das fachadas laterais concentra-se, sobretudo, nos portais, no friso e nos cachorros. O friso é composto por duas fiadas de losangos, sendo todo ele acompanhado por uma orla superior lisa. Os cachorros apresentam diversos motivos decorativos, nomeadamente, a possível representação de uma roldana ${ }^{33}$, o motivo de enxaquetado, duas linhas entrelaçadas (fig. 12), entre outros ${ }^{34}$.

${ }^{33}$ FONTES, op. cit., p. 331.

${ }^{34}$ Para uma descrição pormenorizada de cada cachorro, vide ESPADA, op. cit., pp. 9, 11. 


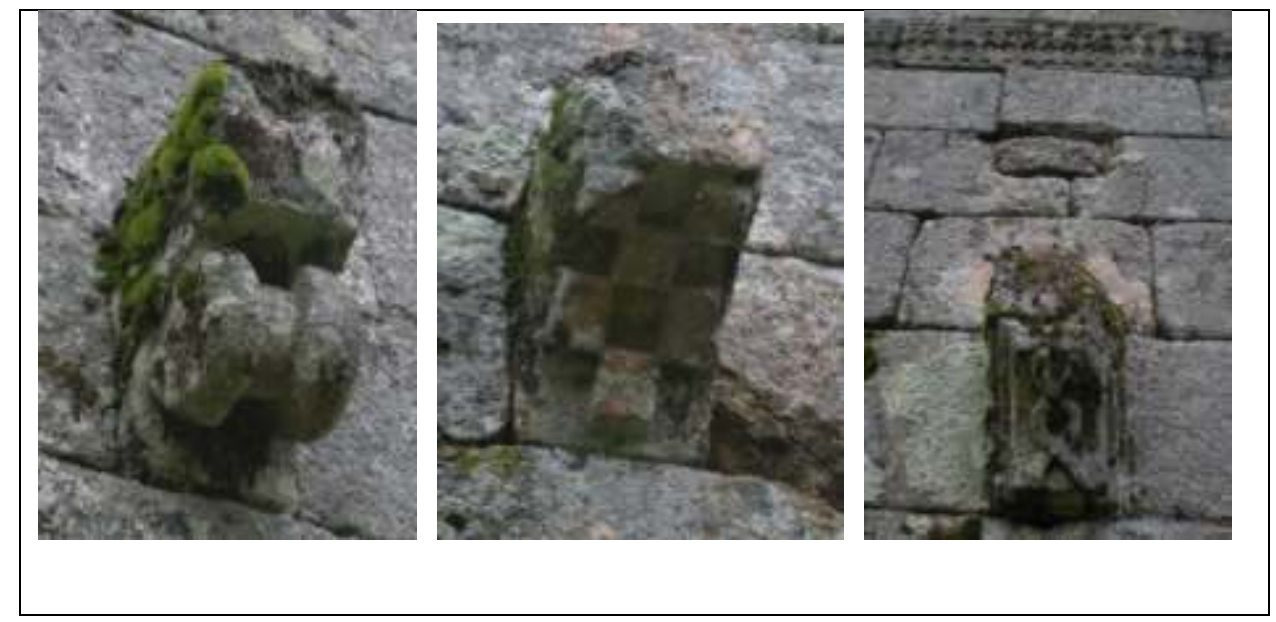

Fig. 12 - Exemplos de cachorros da fachada lateral Sul.

Os portais laterais encontram-se alinhados, junto à cabeceira, e apresentam uma grande simplicidade (fig. 6). Ambos são estruturados pelo arco de volta perfeita, de arestas vivas e incorporado no muro, e apresentam como único elemento decorativo (à excepção das impostas do portal Sul, com uma temática pouco perceptível) a cruz vazada no centro do tímpano, idênticas à do portal principal. Em ambos os portais, o lintel foi cortado numa fase posterior para altear o vão da porta. No lado direito do portal Norte encontra-se a inscrição da datação, gravada em dois silhares (fig. 2).

A cabeceira é caracterizada por uma grande simplicidade decorativa e estrutural. Como já foi referido, constitui uma estrutura poliédrica de base rectangular, com cobertura de pendor único, encimado por uma cruz. A própria fachada oriental (fig. 13), bem como a presença da cornija original, permitem observar que a cabeceira teria sido originalmente coberta por um telhado de duas águas, a uma cota mais baixa que a actual. A cabeceira terá sido «... alteada para se construir o segundo piso da ala dos monges, passando a cobertura do telhado a ser de uma só água, com pendor Sul - Norte para evitar problemas de infiltração na ala dos monges» ${ }^{35}$. Sensivelmente a meio, no antigo ponto de inflexão, colocou-se a cruz de empena, gótica.

\footnotetext{
${ }^{35}$ ESPADA, op. cit., p. 13.
} 


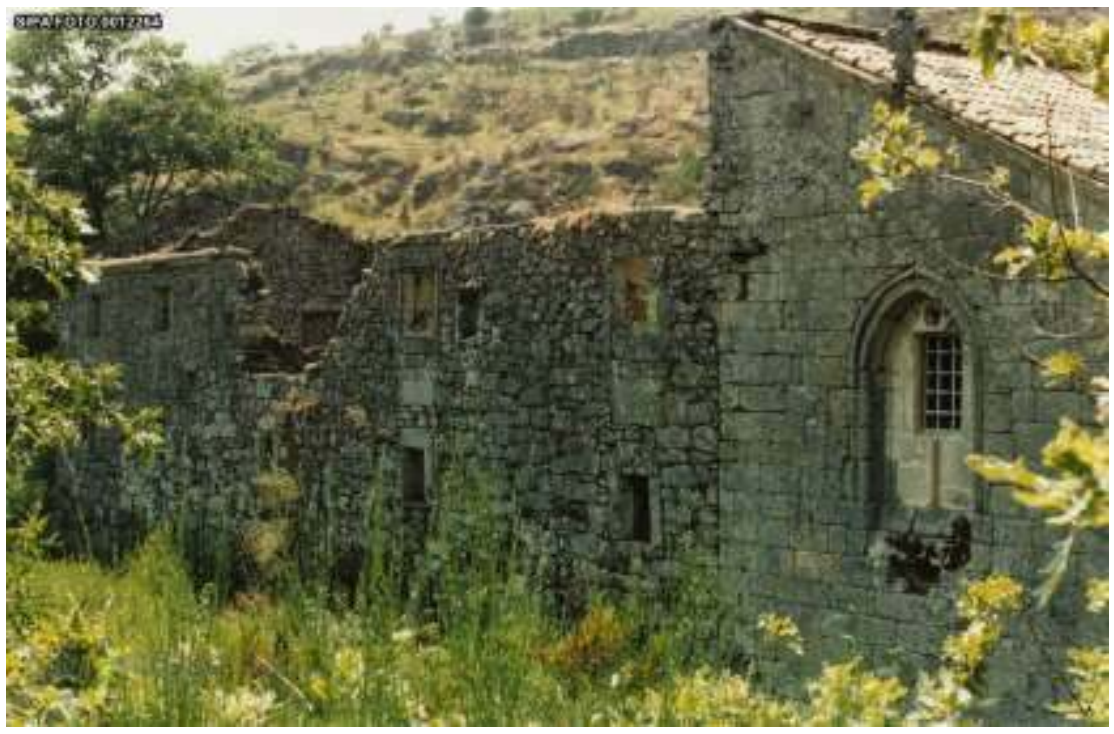

Fig. 13 - Fachada oriental da igreja [www.monumentos.pt].

A fachada oriental é aberta por uma janela de arco quebrado, com tímpano trilobado vazado, semelhante à que se abre também na fachada Norte da cabeceira. Ao nível do plano da fachada existe uma segunda moldura torneada que forma um arco quebrado assente em colunelos lisos. Na base da janela setentrional, encontra-se a escultura de um monge jacente (fig. 4).

Passando ao interior da igreja, a nave (figs. 14 e 15), em termos estruturais, prolonga a clareza de formas, a simplicidade volumétrica e a limpidez mural, aspectos que são contrabalançados pela presença de um friso interrompido pela parte inferior das frestas, ao longo de ambos os alçados laterais (de motivo enxaquetado), bem como pelo tratamento dado aos vãos pelo interior. 


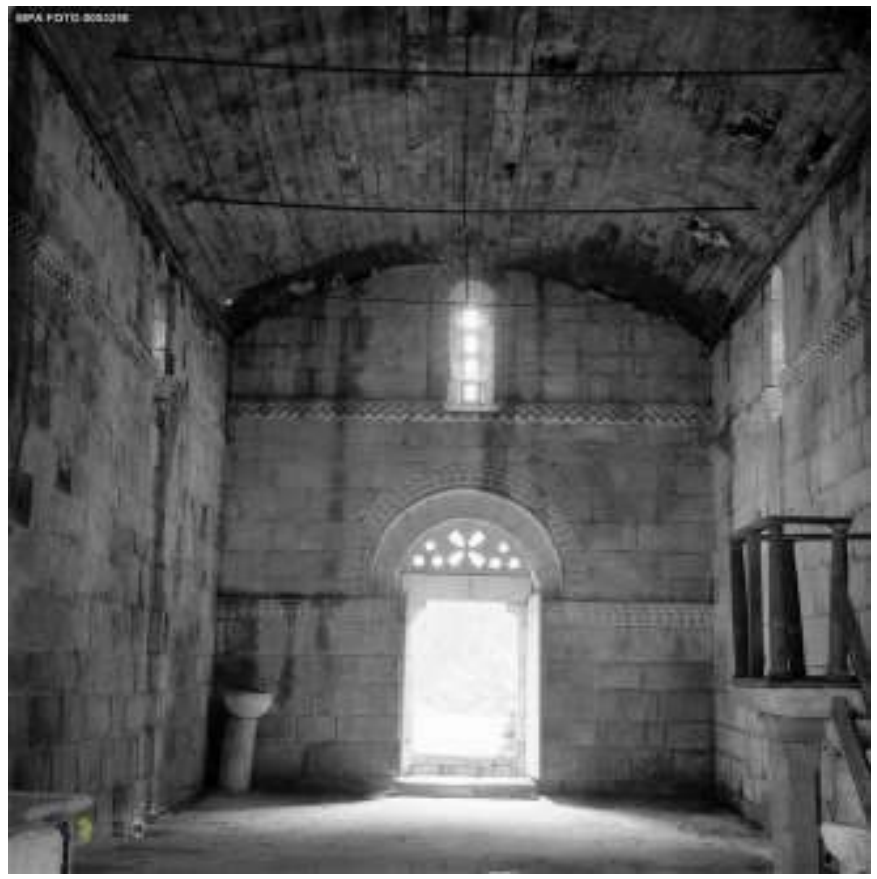

Fig. 14 - Fachada ocidental vista do interior [www.monumentos.pt].

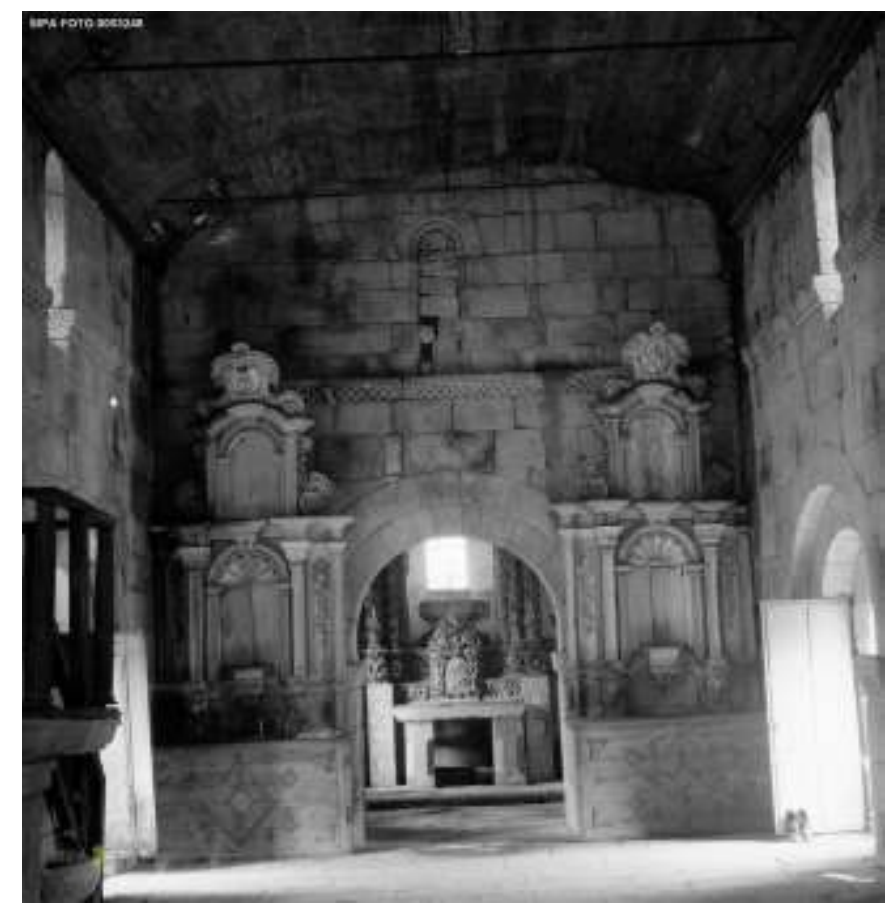

Fig. 15 - Vista para a capela-mor [www.monumentos.pt] .

A nave é caracterizada por uma reduzida fenestração (apenas uma fresta na fachada principal e duas em cada alçado lateral, todas apresentando um alargamento no interior), o que confere ao espaço uma certa obscuridade, como é característico nas igrejas 
românicas. A nave apresenta cobertura em madeira e todo o pavimento, incluindo da cabeceira, é feito em lajes de granito. A fachada ocidental vista do interior é semelhante ao exterior, embora com algumas diferenças - não apresenta friso a enquadrar as arquivoltas; o lintel e as impostas não apresentam decoração; o friso sob as impostas apresenta o motivo de pontas de lança; a fresta apresenta um remate em arco de volta perfeita; existência de um friso com motivo de bilhetes, sob a fresta (fig. 14).

No corpo da igreja encontra-se um púlpito muito simples, posterior à construção do edifício $^{36}$, com varandim e corrimão de madeira, feito a partir de silhares reaproveitadas. $\mathrm{O}$ arco triunfal, ou seja, o arco de passagem para a cabeceira, apresenta duas arquivoltas lisas assentes em ábacos biselados decorados com pérolas ou semiesferas e é ladeado por dois altares laterais ${ }^{37}$. Uma fresta de volta perfeita, rasgada sobre o arco triunfal (actualmente entaipada), recebeu molduras e uma decoração de volutas de tratamento superficial. A decoração barroca do muro do arco triunfal e da abside (habitual nas igrejas de peregrinação) contrasta com a grande simplicidade da nave ${ }^{38}$.

A cabeceira, primitivamente românica, constitui uma estrutura gótica, formada por um corpo rectangular com abóbada de cruzaria de ogivas. As ogivas ou nervuras, de perfil rectangular e arestas chanfradas, são lançadas a partir de um nível bastante baixo e apoiadas em mísulas prismáticas colocadas nos ângulos da cabeceira, que partem a cerca de um metro do chão. Estas, apesar da sua relativa densidade, dispensaram quaisquer elementos de reforço no exterior do muro. A chave da abóbada é simples, possivelmente com decoração, embora esta seja imperceptível. Nos alçados setentrional e oriental abrem-se largos janelões em arco quebrado, fazendo com que este seja o espaço mais iluminado da igreja. À esquerda da janela há um pequeno nicho, apanhando dois silhares, com arco ultrapassado talhado num único silhar. Por cima deste nicho surge gravado no silhar uma marca de canteiro, em linha dupla, representando o símbolo do infinito. Este encontra paralelos no dormitório de Alcobaça, no interior da igreja de Tarouca, entre outros ${ }^{39}$. O altar-mor será já do século XVII ${ }^{40}$.

\footnotetext{
${ }^{36}$ Segundo Lourenço Fontes, já do século XIX (FONTES, op. cit., p. 330).

${ }^{37}$ Segundo Lourenço Fontes, já do século XX (FONTES, op. cit., p. 334).

${ }^{38}$ GRAF, op. cit., p. 269.

${ }^{39}$ ESPADA, op. cit., p. 18.
} 


\section{Elementos decorativos - Influências e Paralelos}

A historiografia da Arte românica tem vindo a considerar a existência de variantes regionais ou distinções culturais, de implicações artísticas, que terão sido determinadas pelas condições geográficas, políticas e sociais de cada região. Mais recentemente, esta tese, tida como absoluta, referente à «geografia da arquitectura românica», tem vindo a ser questionada, sendo agora defendida a hipótese, mais plausível, de que factores externos não terão tido uma influência tão marcante sobre a própria arquitectura e que as diferenças, ou supostos «regionalismos», poderão, antes, ser consideradas como «variações de um mesmo tema» ${ }^{41}$.

O seu despojamento estrutural, densidade mural (conferida pelo uso do granito e pela reduzida fenestração, em número e tamanho) e bom acabamento; a planta de uma só nave e capela-mor de terminação recta; a existência de três portais (ocidental e laterais, sendo o portal Sul virado para o claustro); a reduzida fenestração, criando interiores obscuros, e iluminação concentrada sobretudo na cabeceira; o privilégio dado à cabeceira, em termos estruturais e estéticos; o despojamento decorativo e concentração da ornamentação nos portais, arco triunfal, cabeceira, cachorros e frisos que atravessam as paredes exteriores e interiores, constituem, todos eles, elementos que permitem definir a igreja do mosteiro de Santa Maria das Júnias, apesar das diversas intervenções posteriores, como um edifício característico do românico português.

A escultura românica desenvolvia-se na e pela arquitectura, isto é, aplicada em locais específicos do suporte arquitectónico, funcionava como uma forma de marcação dos próprios espaços. Os espaços privilegiados foram sobretudo, o portal ocidental, como passagem do espaço profano para o sagrado; o arco triunfal, como passagem para a capela-mor; e a cabeceira como o espaço do sagrado por excelência.

\footnotetext{
${ }^{40}$ FONTES, op. cit., p. 333.

${ }^{41}$ RODRIGUES, op. cit., p. 221; cf. BOTELHO, Maria Leonor - A Historiografia da Arquitectura da Época Românica em Portugal (1870-2010). 2 vols.. Porto: Tese de Doutoramento em História da Arte Portuguesa apresentada à Faculdade de Letras da Universidade do Porto, policop., 2010, pp. 389-402.
} 
Apesar de marginal do ponto de vista geográfico, esta igreja encontra-se integrada, em termos artísticos e culturais, na designada «corrente bracarense», que constitui uma das grandes zonas de influência artística do território português, associada à diocese de Braga $^{42}$ e aos Beneditinos, e estendendo-se até às bacias do Lima, do Sousa ou do Douro e até à Beira $\mathrm{Alta}^{43}$. Desta «corrente» são característicos os motivos geométricos, vegetais e fitomórficos e as cruzes vazadas nos tímpanos (dos portais oriental e laterais). A cruz, com um sentido apotropaico e cristológico, símbolo da eternidade e perfeição, é o motivo decorativo mais comum nos tímpanos das igrejas românicas do território português. O motivo da cruz de quatro braços iguais, em geral inserido num círculo, aparece pela primeira vez na Sé de Braga, sendo depois irradiado para uma série de outros edifícios $^{44}$. O vazamento da cruz e outros elementos decorativos (nomeadamente as perfurações circulares) remetem para um românico tardio ${ }^{45}$. Outros elementos remetem para a «corrente bracarense», nomeadamente, os lanceolados (pontas de lança), os enxaquetados e os bilhetes, que encontram paralelos na igreja de Manhente (século XII); bem como o friso de motivo de dupla cereja, por exemplo, na igreja S. Pedro de Ferreira ${ }^{46}$.

Importa referir que alguns autores consideram a existência de influências moçárabes, nomeadamente ao nível do arco triunfal, com tendência para o arco de ferradura ${ }^{47}$, bem como visigóticas, cujas reminiscências «... manifestam-se não só pela persistência de um vocabulário ornamental, de carácter geométrico e vegetalista mas também pelos vestígios da presença nártex» ${ }^{48}$.

\footnotetext{
${ }^{42}$ Braga constituía nesta época a mais importante diocese em território nacional, tendo como centro de irradiação episcopal a Sé de Braga.

${ }^{43}$ ALMEIDA, op. cit., p. 90; RODRIGUES, op. cit., p. 221.

${ }^{44}$ A título de exemplo, a Igreja de Unhão (Felgueiras), de São Pedro das Águias (Tabuaço) e de Arnoso (Famalicão).

${ }^{45}$ ALMEIDA, op. cit., p. 114.

${ }^{46}$ Sobre esta temática, conferir ESCOLÁSTICA, Fr. José de Santa - "O Românico Beneditino em Portugal". In SOUSA, Dom Abade Gabriel de - Ora \& Labora. Revista Litúrgica Beneditina, Ano I. Negrelos: Mosteiro de Singeverga, (1954), pp. 25-34, 78-89, 144-151, 203-213, 270-277, 215-230. Ou REAL, Manuel Luís - "A organização do espaço arquitectónico entre Beneditinos e Agostinhos, no séc. XII". In JORGE, Vítor Oliveira - Arqueologia. Porto: Grupo de Estudos Arqueológicos do Porto (GEAP), nº 6 (Dezembro 1982), pp. 118-132.

${ }^{47}$ FONTES, op. cit., p. 321.

${ }^{48}$ ESPADA, op. cit., p. 24.
} 


\section{Conclusão}

O estudo apresentado procurou transmitir o elevado valor da estrutura monástica de Santa Maria das Júnias, e em especial da sua Igreja, do ponto de vista histórico, artístico e, até certo ponto, antropológico. A análise da Arte e da Arquitectura, isto é, da cultura material, é extremamente importante, entre outros motivos, porque nos permite compreender a componente humana que lhe está subjacente e deu origem.

Considera-se importante salientar o facto de que este edifício constitui um dos raros exemplos actuais de um mosteiro que, embora em ruínas, conserva e reflecte na perfeição a localização geográfica e o isolamento pretendido pelo seu fundador, aspecto que se prende ao seu carácter monástico. Este é, de facto, um lugar que preserva perfeitamente a memória de um período e uma cultura marcados essencialmente pelos valores e ideais da Cristandade Ocidental no decorrer da Idade Média. Por outro lado, por constituir um mosteiro fronteiriço, a sua história e evolução está em grande medida associada ao processo de formação de Portugal. No entanto, a importância do mosteiro atravessa não só a Idade Média mas todo o período desde a sua origem até ao século XIX, altura em que é extinto; a igreja, por seu lado, mantém-se importante até aos dias de hoje, sendo nela celebrada a 15 de Agosto, a festa local de Santa Maria das Júnias ${ }^{49}$.

O mosteiro e respectiva igreja têm vindo a ser alvo de estudo e interesse geral desde tempos relativamente recuados, o que se pode comprovar pelo número de documentos já publicados a seu respeito. O edifício foi já alvo de algumas acções de restauro e conservação, bem como de intervenções arqueológicas. Este constitui um elemento importante no turismo da região. Fontes orais deram-me a saber que ainda em 2010 se verificou o desabamento de parte de uma das paredes das dependências monásticas. Pelos motivos apresentados, considero urgente a realização de obras de conservação e restauro, de modo a que não se perca este precioso monumento.

${ }^{49}$ GUERREIRO, Manuel Viegas - Pitões das Júnias. Esboço de monografia etnográfica. Lisboa: Serviço Nacional de Parques, Reservas e Património Paisagístico, 1982, p. 238. 
Data recepção do artigo: 6 de Fevereiro de 2013

Data aceitação do artigo: 3 de Junho de 2013

\section{Bibliografia}

ALMEIDA, Carlos Alberto Ferreira de - "Primeiras impressões sobre a arquitectura românica portuguesa". Revista da Faculdade de Letras do Porto. Porto: Faculdade de Letras. $\mathrm{N}^{\mathrm{o}} 1$, (1972), pp. 65-116.

ANDRADE, António Alberto Banha de, (dir.) - Dicionário de História da Igreja em Portugal. vol. II. Lisboa: Editorial Resistência, 1980-83.

BAPTISTA, José Dias - Montalegre. Montalegre: Município de Montalegre, 2006.

BARROCA, Mário Jorge - "Mosteiro de Santa Maria das Júnias. Notas para o estudo da sua evolução arquitectónica”. Revista da Faculdade de Letras da Universidade do Porto. $2^{\text {a }}$ Série. Porto: Faculdade de Letras da Universidade do Porto. vol. XI, (1994), pp. 417-446.

BARROCA, Mário Jorge - Epigrafia Medieval Portuguesa (862-1422). Lisboa: Fundação Calouste Gulbenkian/Fundação para a Ciência e Tecnologia, 2000.

BOTELHO, Maria Leonor - A Historiografia da Arquitectura da Época Românica em Portugal (1870-2010). 2 vols. Porto: Tese de Doutoramento em História da Arte Portuguesa apresentada à Faculdade de Letras da Universidade do Porto, policop., 2010.

COCHERIL, Dom Maur - Routier des Abbayes Cisterciennes du Portugal. Paris: Fundação Calouste Gulbenkian/Centre Culturel Portugais, 1986. 
COSTA, João Alves da - Montalegre e terras de Barroso. Notas históricas sobre Montalegre, freguesias do concelho e região do Barroso. [s.l.]: Câmara Municipal de Montalegre, 1987.

ESPADA, Delmira - "Mosteiro de Santa Maria das Júnias". Medievalista [Em linha]. $\begin{array}{lllll}\mathrm{N}^{\circ} & 4, & \text { (2008). } & \text { Disponível }\end{array}$ http://www2.fcsh.unl.pt/iem/medievalista/MEDIEVALISTA4/medievalista-espada.htm.

FONTES, Lourenço - "Pitões das Júnias". In Actas do II Encontro Nacional das Associações de Defesa do Património Cultural e Natural. Braga: Associação para a Defesa, Estudo e Divulgação do Património Cultural; Associação Cultural os Amigos do Parque Nacional da Peneda-Gerês, 1981, pp. 317-341.

GRAF, Gerhard N. - Portugal Roman. Vol. 2. Paris: Zodiaque, 1987.

GUERREIRO, Manuel Viegas - Pitões das Júnias. Esboço de monografia etnográfica. Lisboa: Serviço Nacional de Parques, Reservas e Património Paisagístico, 1982.

GUSMÃO, Artur Nobre de - Românico Português do Noroeste. Lisboa: Veja, 1992.

LIMA, Alexandra Cerveira Pinto Sousa - "O Mosteiro de Santa Maria das Júnias. Povoar e organizar um território de montanha”. In Actas do II Colóquio Internacional Cister. Espaços, Territórios, Paisagens. Vol. II. Lisboa: Ministério da Cultura/Instituto Português do Património Arquitectónico, 2000, pp. 615-632.

MATTOSO, José - Religião e Cultura na Idade Média Portuguesa. Lisboa: Círculo de Leitores, 2002.

MAURÍCIO, Rui Paulo Duque - "O Mosteiro de Santa Maria das Júnias: a construção e a paisagem". In Actas do II Colóquio Internacional - Cister. Espaços, Territórios, Paisagens. Vol. II. Lisboa: Ministério da Cultura/Instituto Português do Património Arquitectónico, 2000, pp. 605-614.

REAL, Manuel Luís - "A construção cisterciense em Portugal durante a Idade Média". In RODRIGUES, Jorge (coord.) - Arte de Cister em Portugal e Galiza. Lisboa: Fundação Calouste Gulbenkian, 1998, pp. 42-96. 
RODRIGUES, Jorge - "O mundo românico (sécs. XI-XIII)”. In História da Arte Portuguesa. Vol. I. Lisboa: Círculo de Leitores, 1995, pp. 180-331.

S. TOMÁS, Frei Leão de - Beneditina Lusitana. Tomo II. Ed. Crítica de José Mattoso. Lisboa: Imprensa Nacional-Casa da Moeda, 1974.

YAÑEZ NEIRA, Ma Damian - Datos para la historia del Monasterio de Junias. Separata da revista Bracara Augusta. Tomo XXXII. Braga: [s.e.], 1978.

\section{Fontes cartográficas}

C.M.P., folha 18, Montalegre, esc. 1:25000, 1992.

Google Earth [Janeiro de 2013].

\section{Fontes digitais}

www.igespar.pt [Janeiro de 2013].

Www.monumentos.pt [Dezembro de 2012]. 


\section{COMO CITAR ESTE ARTIGO}

\section{Referência electrónica:}

LOVEGROVE, Sofia - “A Igreja do Mosteiro de Santa Maria das Júnias (Vila Real) Um estudo histórico-arquitectónico". Medievalista [Em linha]. №14, (Julho - Dezembro 2013). [Consultado dd.mm.aaaa]. Disponível em http://www2.fcsh.unl.pt/iem/medievalista/MEDIEVALISTA14/lovegrove1404.html. ISSN 1646-740X.

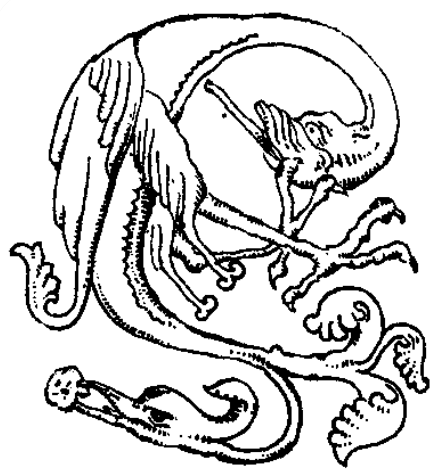

